\title{
Kadar Low Density Lipoprotein (Ldl) Kuning Telur Puyuh Jepang (Coturnix coturnix japonica L.) setelah Pemberian Tepung Kunyit (Curcuma longa L.) pada Pakan
}

\section{Low Density Lipoprotein (LDL) Yolk Levels in Japanese Quail Eggs (Coturnix japonica L.) After Giving Turmeric Powder (Curcuma longa L.) on Feed}

\author{
Marco Sentosa ${ }^{1}$, Tyas Rini Saraswati ${ }^{2}$, Silvana Tana ${ }^{3}$ \\ ${ }^{1}$ Program Studi Biologi, Departemen Biologi, Fakultas Sains dan Matematika, Universitas Diponegoro \\ ${ }^{2}$ Departemen Biologi, Fakultas Sains dan Matematika, Universitas Diponegoro \\ Jl. Prof. Soedarto, SH, Tembalang, Semarang \\ *Email : tyasrini@rocketmail.com
}

Diterima 16 November 2016/Disetujui 15 Februari 2017

\begin{abstract}
ABSTRAK
Puyuh merupakan komoditas peternakan dengan berbagai keunggulan, salah satunya adalah produksi telur untuk konsumsi. Telur puyuh memiliki kandungan gizi yang cukup tinggi, namun juga memiliki kadar Low Density Lipoprotein (LDL) yang tinggi. Tujuan dari penelitian ini adalah untuk mengetahui kadar LDL kuning telur pada puyuh Jepang (Coturnix coturnix japonica L.) setelah pemberian suplemen serbuk kunyit pada pakan sebelum masak kelamin. Penelitian ini merupakan penelitian eksperimental dengan Rancangan Acak Lengkap (RAL). menggunakan 15 ekor puyuh betina yang dibagi menjadi 3 kelompok perlakuan dengan 5 kali ulangan. P0: kelompok kontrol yang tidak diberi serbuk kunyit pada pakan. P1: kelompok perlakuan yang diberi suplemen serbuk kunyit dengan dosis $54 \mathrm{mg} / \mathrm{ekor} / \mathrm{hari}$. P2: kelompok perlakuan yang diberi suplemen serbuk kunyit dengan dosis $108 \mathrm{mg} / \mathrm{ekor} / \mathrm{hari}$. Perlakuan ini dimulai saat puyuh berusia 14 hari dan berlangsung selama 30 hari. Parameter yang diamati adalah LDL kuning telur, bobot kuning telur, bobot telur, dan konsumsi pakan. Data yang diperoleh dianalisis menggunakan Analysis of Variance (ANOVA) dan dilanjutkan dengan uji Duncan pada taraf kepercayaan 95\%. Hasil penelitian menunjukkan bahwa pemberian suplemen serbuk kunyit berbeda nyata terhadap kadar LDL kuning telur, namun berbeda tidak nyata terhadap konsumsi pakan, bobot telur, dan bobot kuning telur. Kesimpulan penelitian ini adalah pemberian suplemen serbuk kunyit dapat menurunkan kadar LDL kuning telur.
\end{abstract}

Kata kunci : LDL, kuning telur, puyuh jepang (Coturnix coturnix japonica L.), serbuk kunyit (Curcuma longa L.)

\section{ABSTRAK}

Quail is farm commodity that has many superiority, one of them is eggs productifity for consumption. Quail eggs contains high nutrition, but it was also containe high level of Low Density Lipoprotein (LDL). This research aimed to quantified LDL of eggs yolk after giving turmeric powder on feed before mature sex period. This research was experimental research that use Completely Randomized Design (CRD) method, used 15 Japanese quails (Coturnix coturnix japonica L.) hens that gave 3 treatments with 5 repetitions. P0 was a control without turmeric powder suplementation. P1 was treatment group that gave $54 \mathrm{mg} /$ quail/day turmeric powder. P2 was treatment group that gave $108 \mathrm{mg} /$ quail/day turmeric powder. The treatment started from 14 days old quail for 30 days next on. Parameter that observed are levels of LDL yolk, weight of yolks, weight of eggs, and daily food consumption. Data was analysed with Analysis of Variance (ANOVA) and continued to Duncan test on 95\% signification. The result of this research showed that, the levels of LDL yolk significant difference but daily food consumption, weight of egg, weight of yolk wasn't show significant difference. The conclusion of this research was turmeric powder could reduce levels of LDL yolk.

Keywords : japanese quail (Coturnix coturnix japonica L.), LDL yolk, turmeric powder (Curcuma longa L.) 


\section{PENDAHULUAN}

Puyuh jepang (Coturnix coturnix japonica L.) merupakan komoditas peternakan yang cukup popular di Indonesia. Keunggulan dari beternak puyuh adalah pertumbuhan tubuh yang cepat, dewasa kelamin yang lebih awal, dan inkubasi relatif cepat (Usman et al., 2008).

Telur puyuh dimanfaatkan sebagai sumber bahan makanan karena memiliki kandungan protein yang tinggi $(13,05 \mathrm{~g})$, lebih tinggi daripada telur ayam $(12,58 \mathrm{~g})$. Kolesterol yang terdapat pada telur puyuh juga lebih besar, yaitu 844 $\mathrm{mg} / \mathrm{dL}$, sedangkan telur ayam hanya $423 \mathrm{mg} / \mathrm{dL}$, hal tersebut membuat sebagian masyarakat merasa ragu untuk mengkonsumsi telur puyuh (Aviati dkk., 2014).

Low Density Lipoprotein (LDL) adalah lipoprotein yang berguna sebagai pengangkut kolesterol ke jaringan perifer dan berguna untuk sintesis membran dan hormon steroid. Kadar LDL yang terlalu tinggi di dalam tubuh dapat menyebabkan artherosklerosis, yaitu penumpukan endapan jaringan lemak atau plak dalam nadi yang mengganggu sirkulasi yang dapat mengakibatkan stroke dan jantung coroner (Silalahi, 2006)

Salah satu senyawa yang dapat digunakan untuk menurunkan kadar kolesterol adalah kunyit (Clarkson, 2002). Kunyit mengandung kurkumin yang berfungsi sebagai hepatoprotektor yang dapat meningkatkan fungsi hati menjadi lebih baik sehingga metabolisme yang terjadi di dalam hati meningkat. Kandungan lain dari kunyit yaitu fitoestrogen yang membantu sintesis vitelogenin (Somchit et al., 2005 ; Silva, 2008).

Kandungan kunyit tersebut bekerja sinergis untuk meningkatkan sintesis vitelogenin yang akan dibawa ke dalam folikel ovarium sehingga meningkatkan jumlah hirarki folikel yang berkembang. Banyaknya folikel yang berkembang menyebabkan kolesterol terdestribusi kedalam banyak folikel. Pemberian dosis kunyit pada pakan puyuh didasarkan atas penelitian sebelumnya yaitu sebesar $54 \mathrm{mg} / \mathrm{ekor} / \mathrm{hari}$ dan diberikan sebelum masak kelamin (Saraswati., 2013).

Hasil penelitian tersebut menunjukkan bahwa pengaruh kunyit untuk menurunkan kadar kolesterol LDL kuning telur belum maksimal.
Dosis kunyit yang diberikan pada penelitian ini ditingkatkan menjadi $108 \mathrm{mg} / \mathrm{ekor} / \mathrm{hari}$. Pemberian dosis tersebut diharapkan dapat memberikan pengaruh yang lebih baik untuk menurunkan kadar LDL kuning telur.

\section{METODE PENELITIAN}

\section{Waktu dan Tempat}

Penelitian ini dilaksanakan selama 5 bulan yaitu dari bulan april hingga september 2014 di Laboratorium Biologi Struktur dan Fungsi Hewan (BSF-H), Jurusan Biologi, Fakultas Sains dan Matematika, Universitas Diponegoro, Semarang. Analisis kadar LDL kuning telur puyuh Jepang dilakukan di Laboratorium Wahana (AnalysisChemical Distributor-Consultant) Semarang.

\section{Bahan Penelitian}

Bahan-bahan yang digunakan dalam penelitian ini yaitu 45 ekor puyuh Jepang (Coturnix coturnix japonica L.) betina, serbuk kunyit (Curcuma longa L.), pakan standar puyuh, air minum, vaksin, dan vitamin B kompleks.

\section{Hewan Uji}

Hewan uji yang digunakan pada penelitian ini adalah puyuh Jepang (Coturnix coturnix japonica L.) betina sebanyak 45 ekor yang memiliki bobot tubuh homogen diambil secara acak dari 100 ekor puyuh Jepang betina. Puyuh Jepang yang sudah diambil tersebut dibagi dalam 3 kelompok perlakuan. Masing-masing kelompok perlakuan terdiri dari atas 3 ekor puyuh, masingmasing dengan 5 kali ulanga. Adapun 3 kelompok perlakuan tersebut adalah.

- P0 adalah kelompok kontrol

- P1 adalah kelompok perlakuan dengan dosis kunyit sebanyak $54 \mathrm{mg} / \mathrm{ekor} / \mathrm{hari}$

- P2 adalah kelompok perlakuan dengan dosis kunyit sebanyak $108 \mathrm{mg} / \mathrm{ekor} / \mathrm{hari}$

\section{Penimbangan dan Pencampuran Pakan}

Serbuk kunyit sesuai dosis perlakuan yang diberikan yaitu sebanyak $54 \mathrm{mg} / \mathrm{ekor} / \mathrm{hari}$ dan 108 $\mathrm{mg} / \mathrm{ekor} / \mathrm{hari}$. Penimbangan yang telah dilakukan 
tersebut masing-masing dikalikan 3, karena serbuk kunyit diberikan pada satu kandang yang terdiri dari 3 ekor puyuh Jepang sehingga untuk P1 menjadi $162 \mathrm{mg} / 3$ ekor/hari dan untuk P2 menjadi $324 \mathrm{mg} / 3$ ekor/hari. Serbuk kunyit pada setiap perlakuan dicampurkan dengan pakan standar puyuh sebanyak 30g/kandang/hari dan ditambahkan air sebanyak 10 kali spray. Campuran pakan selanjutnya dikeringanginkan di atas kertas pada tempat yang tidak terkena sinar matahari langsung.

\section{Parameter yang diamati}

Parameter yang diamati dalam penelitian ini adalah kadar LDL kuning telur dengan data pendukung berupa bobot kuning telur, bobot telur, dan konsumsi pakan harian. Kadar LDL kuning telur dianalisis menggunakan metode spektrofotometri dengan CHOD-PAP.

\section{Analisis data}

Data dianalisis menggunakan uji ANOVA pada taraf kepercayaan 95\% $(\alpha=0.05)$ dan dilanjutkan dengan uji Duncan (Santoso, 2000). Software SPSS versi 17.0 digunakan untuk membantu proses pengolahan data.

\section{HASIL DAN PEMBAHASAN}

\section{Kadar LDL Kuning Telur}

Hasil analisis dengan ANOVA pengaruh pemberian serbuk kunyit terhadap kadar LDL kuning telur puyuh menunjukkan perbedaan yang nyata $(\mathrm{P}<0,05)$. Semakin tinggi perlakuan hingga $108 \mathrm{mg} / \mathrm{ekor} / \mathrm{hari}$, maka semakin menurun kadar LDL telur puyuh. Kunyit mengandung kurkumin yang berfungsi sebagai antioksidan untuk memperbaiki sel dan jaringan, termasuk sel-sel dan jaringan hati. Sel hati yang terlindungi dapat meningkatkan metabolisme yang terjadi didalam hati menjadi optimum (Masubuchi and Horie, 2007). Fitoestrogen yang terkandung pada kunyit memiliki fungsi seperti hormon estrogen, yaitu untuk pertumbuhan organ reproduksi, pembentukan vitelogenin didalam hati dan menstimulasi saluran reproduksi untuk persiapan pembentukan telur (Widowati, 2013). Kandungan kurkumin dan fitoestrogen dalam kunyit bekerja sinergis dalam perbaikan fungsi hati yang menyebabkan sintesis vitelogenin meningkat. Vitelogenin menstimulasi pertumbuhan hirarki folikel ovarium, sehingga jumlah hirarki folikel meningkat. Penurunan kadar LDL diduga berkaitan dengan banyaknya jumlah hirarki folikel yang berkembang. LDL yang di produksi oleh hati akan terdistribusi ke banyak folikel, sehingga dapat menurunkan kadar LDL pada kuning telur. Saraswati et al. (2013) menyatakan bahwa, penurunan kadar kolesterol dan lemak pada telur disebabkan semakin banyak folikel yang berkembang pada puyuh yang diberi suplemen serbuk kunyit. Hal ini mnyebabkan kolesterol dan lemak sebagai komponen penyusun kuning telur akan terdistribusi ke sejumlah folikel yang berkembang, sehingga kandungan kolesterol dan lemak pada masing- masing telur akan mengalami penurunan. Kadar kolesterol pada telur dapat berkurang hingga $11.15 \%$, sedangkan kadar lemak pada telur dapat berkurang hingga $10.76 \%$.

\section{Bobot Kuning Telur}

Hasil analisis dengan ANOVA pengaruh pemberian serbuk kunyit terhadap bobot kuning telur puyuh menunjukkan hasil yang tidak berbeda nyata $(P>0,05)$. Bobot kuning telur sangat dipengaruhi oleh vitelogenin. Vitelogenin adalah suatu protein yang menjadi bahan pembentuk kuning telur (Silva, 2008). Hasil yang diperoleh tidak berbeda nyata karena vitelogenin yang diproduksi digunakan untuk mengembangkan folikel nonhirarki menjadi folikel hirarki, sehingga membuat proses ovulasi berlangsung cepat. Siklus ovulasi yang cepat membuat bobot kuning telur tidak bertambah karena folikel akan segera diovulasikan ketika folikel telah matang. Sintesis vitelogenin yang dihasilkan oleh sel hepatosit akan memacu perkembangan hirarki folikel. Folikel yang cepat berkembang akan terdorong untuk segera mengalami ovulasi, sehingga akan mempercepat siklus ovulasi. Saraswati (2013) menyatakan, pemberian serbuk kunyit dapat 
menyebabkan terjadinya pemendekan siklus ovulasi selama 5 jam 35 menit.

Tabel 1. Hasil analisis rata-rata kadar LDL kuning telur puyuh, bobot kuning telur, bobot telur dan konsumsi pakan setelah pemberian suplemen serbuk kunyit dengan dosis yang berbeda.

\begin{tabular}{lccc}
\hline \multirow{2}{*}{ Variabel } & \multicolumn{3}{c}{ Perlakuan } \\
\cline { 2 - 4 } & $1,396^{\mathrm{a}} \pm 0,067$ & $1,287^{\mathrm{b}} \pm 0,030$ & $1,210^{\mathrm{c}} \pm 0,049$ \\
\hline $\begin{array}{l}\text { Kadar LDL kuning telur } \\
\text { (g/100g) }\end{array}$ & $3,470^{\mathrm{a}} \pm 0,387$ & $3,700^{\mathrm{a}} \pm 0,379$ & $3,868^{\mathrm{a}} \pm 0,480$ \\
Bobot kuning telur $(\mathrm{g})$ & $11,008^{\mathrm{a}} \pm 1,693$ & $11,834^{\mathrm{a}} \pm 0,991$ & $11,808^{\mathrm{a}} \pm 0,892$ \\
Bobot telur $(\mathrm{g})$ & $20,700^{\mathrm{a}} \pm 0,915$ & $20,369^{\mathrm{a}} \pm 1,201$ & $19,878^{\mathrm{a}} \pm 0,391$ \\
Konsumsi Pakan (g/ekor/hari) & & & \\
\hline
\end{tabular}

Keterangan : Angka yang diikuti dengan huruf superskrip yang sama pada baris yang sama menunjukkan perbedaan tidak nyata pada taraf kepercayaan $95 \%(\mathrm{P}>0,05)$. P0 : kontrol, P1 : puyuh dengan perlakuan dosis kunyit sebanyak $54 \mathrm{mg} / \mathrm{ekor} / \mathrm{hari}, \mathrm{P} 2$ : Puyuh dengan perlakuan dengan dosis kunyit sebanyak $108 \mathrm{mg} / \mathrm{ekor} / \mathrm{hari}$.

\section{Bobot Telur}

Hasil analisis dengan ANOVA pengaruh pemberian serbuk kunyit terhadap bobot telur puyuh menunjukkan hasil yang tidak berbeda nyata $(\mathrm{P}>0,05)$. Faktor yang dapat mempengaruhi bobot telur diantaranya adalah faktor konsumsi pakan.

Konsumsi pakan yang berbeda tidak nyata menyebabkan bobot telur juga menjadi tidak berbeda nyata. Pakan merupakan hal yang sangat penting dalam proses pembentukan telur karena sebagian besar zat yang berada didalam telur seperti karbohidrat, lemak dan protein berasal dari pakan. Zat gizi makanan yang mempengaruhi bobot telur adalah protein dan asam amino.

Defisiensi protein dapat menyebabkan rontok bulu atau produksi menurun bahkan berhenti sama sekali disertai menurunnya bobot telur. Faktor lain yang mempengaruhi bobot telur adalah bobot kuning telur, bobot putih telur, dan bobot kerabang telur. Bobot kuning telur yang tidak berbeda nyata berpengaruh terhadap sekresi albumin, sehingga akan mempengaruhi bobot total telur. Sekresi albumin akan terpicu jika kuning masuk ke dalam lumen magnum. Semakin besar ukuran kuning telur yang masuk kedalam magnum maka semakin banyak albumin yang akan disekresikan.

\section{Konsumsi Pakan Harian}

Hasil analisis dengan ANOVA pengaruh pemberian serbuk kunyit terhadap konsumsi pakan harian menunjukkan hasil yang tidak berbeda nyata $(\mathrm{P}>0.05)$. Hal ini menunjukkan bahwa pemberian suplemen serbuk kunyit pada pakan tidak mempengaruhi konsumsi pakan pada puyuh.

Faktor yang dapat mempengaruhi konsumsi pakan diantaranya adalah palatabilitas. Palatabilitas merupakan derajat kesukaan pada makanan tertentu yang dipilih dan dimakan. Aviati dkk. (2014), menjelaskan bahwa pemberian kunyit dengan dosis $54 \mathrm{mg} /$ hari tidak mempengaruhi palatabilitas pakan sehingga tidak mempengaruhi konsumsi pakan puyuh. Konsumsi pakan juga dipengaruhi oleh keadaan lingkungan. Suhu dan kelembaban di lingkungan kandang puyuh selama penelitian ini rata-rata adalah $25,47^{\circ} \mathrm{C}$ dan $64,16 \%$.

Suprijatna dkk. (2005) menyatakan bahwa, unggas mampu berproduksi stabil pada kisaran suhu $10-30^{\circ} \mathrm{C}$ dan kelembaban $30-80 \%$. Suhu dan kelembaban yang masih dalam taraf normal membuat puyuh dapat hidup dengan nyaman dan mengkonsumsi pakan dengan baik. Konsumsi pakan pada penelitian yaitu antara 20,7 - 19,9g per hari, sesuai dengan penelitian Saraswati and Tana. (2016) yang menunjukan bahwa konsumsi pakan rata-rata puyuh jepang adalah 19,32 - 20,31. 


\section{KESIMPULAN}

Hasil penelitian ini menunjukan bahwa pemberian sumplemen serbuk kunyit (Curcuma Longa L.) mampu menurunkan kadar LDL kuning telur.

\section{DAFTAR PUSTAKA}

Aviati, V., Mardiati S. M., dan Saraswati T. R. 2014. Kadar Kolesterol Telur Puyuh Setelah Pemberian Tepung Kunyit Dalam Pakan. Buletin Anatomi dan Fisiologi. Volume XXII, Nomor 1, 58-64.

Clarkson, T. B. 2002. Fourth International Symposium on the Role of Soy in Preventing and Treating Chronic Disease. JN The Journal of Nutrition. 132

Masubuchi, Y. and Horie, T. 2007. Toxicological Significance of Mechanism-Based inactivation of Cytochrome P450 Enzymes by Drugs. Critical Reviews in Toxicology. 37: 389-412.

Santoso, S. 2000. Buku latihan SPSS Statistik Parametrik. Jakarta: PT. Elex Media Komputindo.

Saraswati, T. R. 2013. Optimalisasi Kondisi Fisiologis Puyuh Jepang (Coturnix coturnix japonica) dengan Suplementasi Serbuk Kunyit (Curcuma longa). Disertasi. Progam Doktor Institut Pertanian Bogor, Bogor.

Saraswati, T. R. and Tana, S. 2016. Effect of Turmeric Powder Supplementation to The Age of Sexual Maturity, Physical, and Chemical Quality of The First Japanese Quail's (Coturnix japonica) Egg. Biosaintifika 8 18-24

Silalahi, J. 2006. Fats and Oils: Modification and Substitution. Lecture Notes. Postgraduate Section. Medan: Universitas Sumatera Utara Press.

Silva, W. A. 2008. Quail egg yolk (Coturnix coturnix japonica) enriched with omega-3 fatty acids. LWT - Food Science and Technology 42 (2009) 660-663.
Somchit, M.N., A. Zuraini, A. Bustamam, M.R. Sulaiman and R. Nuratunlina. 2005. Protective Activity of Tumeric (Curcuma longa) in Paracetamol Induced Hepatotoxicity in Rat. International Journal of Pharmacology 1(3):252-256.

Suprijatna, E., Atmomarsono, U., dan Kartasudjana, R., 2005. Ilmu Dasar Ternak Unggas Cetakan I. Jakarta: Penebar Swadaya.

Usman, B. A., Mani, A. U., El-Yuguda, A. D., and Diarra, S. S. 2008. The effect of suplemental ascorbic acid on the development of newcastle disease in japanese quail exposed to high ambient temperature. International Journal of Poultry Science 7(4): 328-332.

Widowati, S. 2013. Pengaruh Tepung Kunyit (Curcuma longa L.) Terhadap Kadar kolesterol dan Kadar Trigliserida darah burung puyuh (Coturnix coturnix japonica L.). Skripsi. Jurusan Biologi FSM UNDIP, Semarang. 